Journal of Language Teaching and Learning, Linguistics and Literature

ISSN 2338-4778 (Print)

ISSN 2548-4129 (Online)

Volume 7, Number 2, December 2019

pp. 61-71

\title{
The Use Of Think, Pair And Share (TPS) Strategy in Teaching Reading Skill
}

\author{
Yanpitherszon Liunokas \\ yanpiters69@gmail.com \\ Nusa Cendana University, Kupang, NTT, Indonesia \\ Received : 13 September 2019; Accepted : 3 November 2019
}

\begin{abstract}
This research deals with the teaching reading through think pair share strategy (TPS) at the fourth semester students of English Education Department, Nusa Cendana University, Kupang, NTT. The population of this research is the Fourth Semester Students of English Education Department, Nusa Cendana University, Kupang, NTT. Reading test was the instrument of this research. Based on the findings and discussion, the researcher concludes that the use of think pair share strategy parallel writing technique is effective in developing students' vocabulary in writing at the Fourth Semester Students of English Education Department, Nusa Cendana University, Kupang, NTT. It was proven by there was a significant difference between the students' mean score of pretest and posttest. In pretest, the students' mean score is 26 and the students' score in posttest is 51. In addition, the result of statistical analysis for level of significance $(p=0.05)$. The probability value was smaller than $\alpha(0.00<0.05)$. it indicated that there is significant differences between the result of pre-test and post-test after giving treatment in building students' reading skill ng by applying think pair share strategy (TPS) to the fourth semester students of English Education Department, Nusa Cendana University, Kupang, NTT.
\end{abstract}

Keywords: think pair share strategy, reading skill

\section{Introduction}

Reading is one of the important aspects in learning English, because through reading we can get a lot of information. By reading, people will be able to think critically and able to develop in any case. It cannot be denied that people who are successful in academics are those who familiarize themselves 
in cultivating reading and fostering a sense of love towards reading. Since reading of any sort is an activity, all reading must to some degree be active. Completely passive reading is impossible; we cannot read with our eyes immobilized and our minds asleep. Hence when we contrast active with passive reading, our purpose is, first, to call attention to the fact that reading can be more or less active, and second, to point out that the more active the reading the better. One reader is better than another in proportion as he is capable of a greater range of activity in reading and exerts more effort. He is better if he demands more of himself and of the text before him (Mortimor, 2017).

According to Anderson (1999: 1) reading is an active, fluent process that involves the reader and the reading material in constructing the meaning. Furthermore, he notes that meaning does not reside on the printed page, nor is it only in the head of the reader. It means that reading can be constructed by combining the words on the printed page with the reader's background knowledge and experiences. Consequently, the teaching of reading should involve activities which connect the ideas on the text to what students already know.

Think Pair Share strategy is one of the strategies that can be applied in using reading skill because Think Pair Share strategy is potential activity that give students feeling of freedom to express themselves. Think Pair Share strategy are also potentially useful to encourage students of interact with other orally (Dallman, 1982). In this research, the researcher focuses on the Think Pair Share strategy. The implementation of think pair and share strategy involved three major stages of using and learning English, namely: firstly, thinking: Students thought independently about the question that have been posed, forming ideas of their own. Secondly, pairing: Students were discussing their thoughts in pairs. This step allows students to articulate their ideas and to consider those of others. Thirdly, Sharing: Students shared their ideas with other pairs and the whole class (Aruni, 1989).

The reason for using think pair and share strategy is you give more opportunities to students to make in reading skill during the times al located. The researcher assumes that think pair and share strategy are combination between language practice and fun. They can express their ideas freely because they do activities with their friends. This think pair and share strategy is also easy to admirer and flexible in terms of subject matter and design (William, 1991).

Based on the preliminary observation the fourth semester students of English Education Department, Nusa Cendana University, Kupang, NTT., it is 
found that students' ability is still very low because the students face difficulties when they want to English. Because the teacher use text book as teaching materials, Teacher can"t good methods of learning and using appropriate media to give students. They are not motivated to speak English than they also shy speak English. Finally, students are more passive in the classroom. The problem statement of the research was "Does the use of Think Pair and Share strategy improve students' reading skill of the fourth semester students of English Education Department, Nusa Cendana University, Kupang, NTT.?" Then, the objective of this research is to find out whether or not the use of think, pair and share strategy improve students' reading skill of the fourth semester students of English Education Department, Nusa Cendana University, Kupang, NTT. The result of the research is expected to be useful information to the English learner in general who want to improve students' reading skill. The researcher expects this research would be a piece of useful information for the teacher of English especially in teaching reading. It is also expected that the students can be motivated to learn English so that they are able to master English reading skill well and help the student to get interesting strategy in teaching reading skill.. It is also useful for the further researcher as a reference if she wants to conduct a research on reading skill so that the research can be refined.

\section{REVIEW OF RELATED LITERATURE}

\section{Reading Skill}

According to Nunan (1991) reading is a fluent process of readers combining information from a text and their own background knowledge to built meaning. By reading one can relax, interact with feelings and troughs obtain information and improve he science knowledge according to bowmen, reading is an appropriate means to promote a live long learning (life-long learning).By teaching the children a future with provides a technique to explore how "the world" wherever he chose and provide the opportunity to get a goal.

Reading is one of the most important skills in learning language besides listening, writing, speaking. The fundamental goal of any reading activity knows the language. Simanjutak states that reading is process of putting the reader in contact and communication with ideas", Brougthon states that reading is a complex skill that involves the whole series of lesser skills, where skills means relate the ability to recognize stylized shapes which are figure on a ground, curves and lines and dots in pattern (Crystal, 1985).

Richard (2016) revealed that reading means to apply a process to form a 
meaning from written text. Today, not only can be read through the book alone. Reading can be done via the internet. Many news portals and websites that can broaden our knowledge about the world. We also to be good at choosing readings. Choose useful reading. Reading can also be a means of entertainment for people. Therefore reading for creating sound generation and advanced.

Reading is an active process that requires attention or a favorable attitude. Reading is an information process from the text and readers" knowledge which is first function in make a sentence. It may also be defined as learning to recognize the printed symbols that represent language and to respond intellectually and emotionally from the text while reading in additions, it conveys the information that makes and interaction between a reader text itself (Miklulecky, 2007).

Based on the definition by the experts above, the researcher concluded that reading skill is an activity that doing by person to understand the meaning of the text to get the information and knowledge.

\section{The Concept of Think Pair Share}

Think pair and share is cooperative learning strategy in which students work together to solve a problem or answer a question about and assignment reading. The strategy of think pair share (TPS) or thinking pairwise sharing is a type of cooperative learning designed to influence the pattern of student interaction. Meanwhile, Crass (2007) in Sudirman (2016) states that think, pair and share (TPS) technique is a cooperative teaching strategy that includes three components; time for thinking, time for pairing, time for sharing. This thinking pair-share strategy employed from cooperative learning research and waiting time.

First developed by Frank Lyman and colleagues at the University of Maryland as quoted Arends (2013), states that the think pair share is an effective way to create variations in the atmosphere of class discussion patterns. Assuming that all recitations or discussions require settings to control the class as a whole, and the procedures used in think pair share can give students more time to think, to respond and to help each other. Teachers estimate only complete a brief presentation or students read the assignment, or a questionable situation. Now teachers want students to consider more of what has been explained and experienced. Teachers choose to use thinkpair-share to compare whole group questions.

Raba (2017) explained the influence of Think Pair and Share (TPS) on improving students" oral communication skills, to foster critical thinking to provide an opportunity for students to work independently and increase in their self-efficacy, participation, understanding and enjoyment levels after the 
intervention. Dol . M, (2014) found that 99\% students" agreed that think-pair and share activity developed an interest in them to learn. Most of the students agreed that thinking about the problem and writing the solution during the think phased helped them learning concepts more precisely. Also, most of the students agreed that they found the Think-Pair and Share activity is effective. Sugiarto and Sumarsono (2014) explain the implementation of Think-Pair and Share model to improve students' ability in reading narrative text.

Think Pair and Share Strategy engages students" in a step-by-step process that guides them through informational text. The students are able to provide opportunities to talk about a story or text as they read it. It means that the use of Think Pair Share Strategy helps students" to develop their critical thinking based on the information they read. Based on reading rockets journal, the purpose of think pair share is: 1). Helps students to think individually about the topic or answer to a question 2). Teacher students to share ideas with classmates and builds oral communication skills 3 ). Help focus attention and engage students" comprehending the reading material

Arends, (1997) adapted by Tjokrodihardjo, (2003) stated that the teacher can use the following steps (phases):

Step 1: Think (thinking): The teacher asks a question or problem associated with the lesson, and asks students to take a few minutes to think for themselves the answer or problem

Step 2: Pair (pairing): Next the teacher asks the students to pair up and discuss what they have gained. Interactions during the time provided can unify the answer if a proposed question brings together the idea when a specific problem is identified. Normally the teacher gives no more than 4 or 5 minutes to pair.

Step 3: Sharing (sharing): In the final step, the teacher asks the couples to share with the whole class they have been talking about. It is effective to get around the room from couple to couple and continue until about some couples get a chance to report.

Before introducing the Think-Pair-Share strategy to students, the teacher set targets for this lesson. The teacher can choose to use new text that the teacher, the teacher or you may want to develop a series of questions or hints that target the key content concepts the teachers have learned.

Describe the strategies and goals with students, and provide guidance for the discussions that will take place. Explain to students that they will (1) think individually about a topic or answer a question, (2) pair up with a partner and discuss topics or questions; and (3) share ideas with the rest of the class. 


\section{Method}

In this research, the researcher applied a pre-experimental method. Preexperimental design used pre-test and post-test where pre-test was held before treatment and post-test after treatment.

The design of the research is as follow:

$\mathrm{O}_{1} \quad \mathrm{X} \quad \mathrm{O}_{2}$

Where:

$$
\begin{aligned}
& \mathrm{O}_{1}=\text { pre-test } \\
& \mathrm{X}=\text { treatment } \\
& \mathrm{O}_{2}=\text { post-test }
\end{aligned}
$$

(Best 1997:103)

The population of this research was the Fourth Semester Students of English Education Department, Nusa Cendana University, Kupang, NTT. In determining the sample of this research. The researcher took 24 students as sample of this research. The writer used writing test to measure the students' ability to write in English. Before and after giving treatment writing involves

The data was collected by using the procedure below:

1. Giving Pre-test

Firstly, the researcher introduced himself to the students and explained purpose of her coming in their class. The researcher gave pre-test to the students to measure the reading skill of the students before giving treatment.

2. Giving Treatment

The researcher conducted the treatment to the students for sixth meetings by using Think Pair Share Strategy in teaching reading with various themes. the steps as follows: a. Thinking activity in reading a text, b. Pairing activity in discussing and answering questions about the text $\mathrm{c}$. Sharing activity.

3. Giving Post-test

The students were given the same activity in the pre-test after the treatment. The researcher gave reading test and asked the students to answer. It aimed at finding out the students'ability in writing skill after giving treatment..

In analyzing data, the researcher giving score to the students based on the result of their reading test in pre test and post test. The last step of the data analysis was the hypothesis testing. The hypothesis was tested by using inferential statistics. In this case, the researcher used t-test (testing of significance) for paired sample t-test, that is, a test to know the significance difference between the result of students' mean score in pretest and posttest. 


\section{Results}

From the result data analysis, shows that the mean score of the students pretest was 24 and the mean score of posttest was 70 It means that using TPS in teaching reading can enhance the students' achievement especially for the students' reading skill.

From the statistical analysis, the researcher concludes that there is a significant difference between pretest and posttest in enhancing the students' reading ability through TPS technique as a way to deliver learning material. Parallel writing technique is effective in enhancing the students' reading ability. Based on the describing above, the researcher concludes that one of important point that teacher should accommodate he/she should give full the attention especially in reading skill. Therefore, in teaching writing one of technique that the teacher may use this technique in teaching, especially in writing or constructing ideas is greatly expected to make the students easier in generating and expressing their idea in different mode and sense.

After calculating the result of the students' pretest, the mean score and standard deviation of both groups are presented in following table:

\begin{tabular}{lll}
\hline & Pretest & Posttest \\
\hline Mean & 24 & 70 \\
\hline Standard dev. & 8.30 & 10.49 \\
\hline Max & 43 & 64 \\
\hline Min & 21 & 37 \\
\hline
\end{tabular}

The data shows the mean score of the students pretest was 24 and the mean score of posttest was 70. Standard deviation of pretest was 8.22 and the standard deviation of posttest was 11.27 . It means that using think pair share strategy in teaching reading can enhance the students' achievement in reading.

The hypothesis was tested by using inferential statistics. In this case, the researcher used t-test (testing of significance) for paired sample t-test, that is, a test to know the significance difference between the result of students' mean score in pretest and posttest.

Assuming that the level of significance $(\alpha)=0.05$, the only thing which is needed; the degree of freedom (df) $=\mathrm{N}-1$, where $\mathrm{N}=25$, then the t-test is $10.81 P$ is 0.00

From the analysis, the researcher concluded that there was a significant difference between pretest and posttest in enhancing the students' writing ability trough parallel writing technique as a way to deliver learning material. The result of statistical analysis for level of significance $(p=0.05)$ with degree of freedom $(\mathrm{df})=\mathrm{N}-1$, where $(\mathrm{N})=25$, $\mathrm{df}=24$. The probability value was smaller than $\alpha$ $(0.00<0.05)$. it indicated that the alternative hypothesis $(\mathrm{H} 1)$ was accepted and the null hypothesis $(\mathrm{HO})$ was rejected. It means that think pair share strategy is 
effective in enhancing the students' reading ability.

\section{Discussion}

Based on the result of data analysis, the researcher found out that the use of think pair share strategy technique is effective in developing students' reading skill.at the Fourth Semester Students of English Education Department, Nusa Cendana University, Kupang, NTT. Actually, there some technique that we can use to teach speaking but the researcher using parallel writing technique, moreover the application of think pair share strategy gave good effect in enhancing the students' skill in reading.

Based on the data collected, using think pair share strategy in teaching reading can enhance the students' achievement. It was proved by students' score on the reading test. All students' score was improved after conducting the treatment through TPS strategy. The result of this research is supported by Raba (2017) who explained the influence of Think Pair and Share (TPS) on improving students' oral communication skills, to foster critical thinking to provide an opportunity for students to work independently and increase in their self-efficacy, participation, understanding and enjoyment levels after the intervention.

This research has shown that think pair share can increase the students' vocabulary in writing. So, in teaching writing, the students should be have a model of sentence or paragraph that will be a guide text for them in writing and as a basis of knowledge in writing and guide them to express their own ability in parallel work.

\section{Conclusion}

The researcher concludes that the use of think pair share strategy is effective in developing students' reading skill at the Fourth Semester Students of English Education Department, Nusa Cendana University, Kupang, NTT. It was proven by there was a significant difference between the students' mean score of pretest and posttest. The result of statistical analysis for level of significance $(p=0.05)$. The probability value was smaller than $\alpha(0.00<0.05)$. it indicated that there is significant differences between the result of pre-test and post-test after giving treatment in improving students' vocabulary in reading by applying TPS strategy to the Fourth Semester Students of English Education Department, Nusa Cendana University, Kupang, NTT.

\section{References}

A.A.A.M. Raba. (2017). The Influences of Think Pair Share (TPS) on 
IDEAS, Vol. 7, No. 2, December 2019

ISSN 2338-4778 (Print) ISSN 2548-4192 (Online)

Improving Students" Oral Communication Skill In EFL Classroom, Creative Education.Volume 8 (1)

Affan, M. N, Marhaeni \& Dantes. (2013). The Effect of TPS Technique on The English Reading Achievement of the Students" Differing In Achievement Motivation at Grade Eight of SMPN 13 Mataram. EJournal of Islam and Muslim Societies. Volume 8(2)

Arif, Maulana. (2019). The Effect of Using Think Pair Share on Students" Reading Ability applied at the eleventh class SMA 17 Agustus Banyuwangi. E-Journal English Teaching and Learning. Volume 8(2)

Asmawati, A. (2015). The Effectivenes of Skimming-Scanning in Improving Students" Reading Comprehension At the Second Grade of SMK Darussalam Makassar, Eternal.Volume 1(12) 2015.

Bowman. (1991). Definition Reading. Retrieved on $17^{\text {th }}$ september 2019

Brown, et.al., from, http://www.wikipedia.org/wiki/cooperative learning.Retrieved on December $25^{\text {th }} 2019$.

Charles \& Mortimor (2017) How to Read A Book (New York: Simon \& Students" Inc,p.6.

Creswell J. W. (2008). Education Research: Planning Conducting and Evaluating Quantitative and Qualitative Research-International Edition (Boston.Peraon,p.60. accessed on july ${ }^{\text {02th }} 2019$.

David and Roger Johnson, Cooperative Learning, Online http://wwwclcrc.com/ pages/cl.html, 2011. Accessed on December $13^{\text {th }}$ 2019.

Deshpande. A \& Salman .B (2016) Think Pair Share: Aplication of an Active Learning Technique in Engineering and Constructing Management Clases. Annual International Conference Proceedings (52 th $\mathrm{AICP}$ ) the Associated Schools of Construction.

Dol, S .M. (2014).TPS (Think, Pair Share) An Active Learning Strategy to Teach Theory of Computation Course. International journal of Education Research and Technology. Volume 5(4),62-67. 
Farida ,I \& Yeni,P.S. (2017). Think Pair Share as Mhetod to Imprtove Students" Learn8ing Motivation and Learning Achievement. State University of Semarang, Dinamika Pendidikan. Volume 12 (2).

Ginting. S.A.,\& Fenny Friska Sormin. (2016). Improving Students" Achievement

in Reading Comprehension Through Think Pair Share Technique, n.d, $1-16$.

Grabe, W., and Fredical L. S. (2002).Teaching and Reading. Essex: Pearson Education.

Hemant L. S. (2018). Think, Pair, Share (TPS): An Effective Cooperative Learning Strategy For Unleashing Discussion in Classroom Interaction.State Maharshi Dayanand University, International Journal of Research in Social Sciences. Volume 8 Issue 5 (1).

Hulya, Kucukoglu. (2013). Improving Reading Skills Through Effective Reading Strategies, Hecettepe University, Ankara Turkey. ProcediaSocial and Behavioral Sciences. Volume 70 (2013) 709-714.

Jacobs, A. D. (1985).An Introduction to Research in Education: Third Edition.New York: CBS College Publishing

Julian, H. (2009). The Importance of Teaching Academic Reading Skills in First Year. University Courses.International Journal of Res earch Review. Volume 3 (20)

Kurniawati, Cicik. (2011).Bahasa Inggris Program IImu Pengetahuan Alam dan

IImu Pengetahuan Sosial SMA/MA. Surabaya: Intan Parwira.

Lee, C., Li, H., \& Shahril, M.(2018) Utilising the Think-Pair Share Technique in the Learning of Probability. International Journal on Emerging Mathemarics Education. Volume 2(1), 46-64.

Lie, Anita. (2010). Mempraktikkan Cooperative Learning Di ruang-ruang Kelas.

Jakarta: Grasindo.

Mahmoud, K. (2013). Think Pair Share: A Teaching Strategy to Enhance Students" Critical Thinking. Educational Research Quarterly. Volume $36(4)$

Marta.Dallman, et. al. (1982). The Teaching of Reading. New York: M Ediger 
1982.

Martha, M.I., Emmanue, 1. \& Seraphina, M. (2015). Effect of think-pair-share strategy on secondary school mathematics students" achievement and academic self-esteem in fraction. American International Journal of Contemporary Scientific Research. Volume, 2 (2), 141-147.

Opentexbc, Quasy Experimental Research, http:/opentexbc.ca/research/quasi experimental/. Accessed on $26^{\text {th }}$ January 2019

Pardede, Parlindungan ( 2017 ) A review on Reading Theories and Its Implication on the Teaching of Reading. Retrieted on 19th May 2017, from https://www researchgate.net/publication/321228081_A_Review_on_Reading_The ori es_And_Its_Implication_to_he_Teaching_On_Reading.

Ridwan, A.n. (2016). Using Think Pair Share (TPS) Tecchnique To Improve The Reading Comprehension of Class VIII G Students" of SMABN 1 Sleman in The Academic Year of 2016/2017. Unpublised Thesis, Yogyakarta State Universaity of Yogyakarta.

Sabsuha, S. (2013) Think Pair Share Technique To Improve Students Reading Comprehension. ICE-Ed Comperence. ELT Prectices In Asia. College \& Opportunities. Universitas Iqro" Buru Maluku (online) May 9th 2019.

Sari, D. P. (2015). An Analysis of Students" Reading Comprehension Based on The Four Levels Comprehension Skills (A Study at Ther Second Year Students" of SMANB 10 Bengkulu Academic Year 2014/2015. University of Bengkulu. Indonesia (online). May 9th 2019.

Tint, S. S. \& Nyuut. E. E. (2015). Collaborative learning with think-pair-share Technique. Computer Application, An International Journal (CAIJ). Volume, 2(1), p. 1-11.

Titsankaew, P. (2015).The Effect of Using Cooperative Learning on Students'

Achievement and Attitude toward Mathematics. Procedding of the International conference on language,education, humanities \& innovation, 83-7.

Wahyuni, S. \& Badriyah Laelatul (2015) Using Think Pair Share Mhetod To Improve The Reading Skills on Narrative Text of Students" of MtsN Kunir Blitar.

Yudistirah, A . D. (2015). The Influences of Think Pair Share (TPS) On Students"

Reading Narrative Text.Jakarta: UIN Syarif Hidayatullah Jakarta. 
Yanpitherszon Liunokas :

The Use of Think, Pair And Share (TPS) Strategy in Teaching Reading Skill

Yulianingsih, L.(2017). The Use of Think Pair Share Technique in Teaching Reading To The Seventh Grade of Senior High School. University of Swadaya Gunung Jati. Academic Journal, PERSPECTIVE Language Educational and Literaturen. Volume 5(2) 